\title{
MENGATASI PECANDU NARKOBA (Pendekatan Psikologi Dakwah)
}

\author{
Oleh : Rubino
}

\begin{abstract}
Abstrak
Narkotika dan Obat-obat terlarang yang disingkat Narkoba atau dengan istilah lain disebut NAZA (Narkotika, Alkohol dan Zat Adiktif) merupakan zat- zat yang apabila dipergunakan secara tidak benar maka sangat berbahaya bagi kesehatan manusia. Orang yang mengalami kecanduan narkoba, bukan saja membahayakan kesehatan jasmaninya tetapi juga kesehatan rohaninya bahkan akan dapat meng-hancurkan kesehatan sosial. Oleh karena itu, dengan begitu besarnya dampak negatif dari kecanduan narkoba ini, maka tentunya harus senantiasa diupayakan solusi untuk mengatasinya agar bagi para pecandu narkoba dapat menghentikan perbuatannya dan bagi mereka yang belum terkena dapat terhindar dari dampak negatif narkoba tersebut, dan salah satu solusi untuk mengatasi pencandu narkoba tersebut yaitu melalui pendekatan Psikologi Dakwah.
\end{abstract}

Kata Kunci: Narkoba dan Psikologi Dakwah

\section{Pendahuluan}

Ketentraman dan kebahagian merupakan andalan dari setiap keluarga, namun hal ini akan terusik bila ada salah seorang dari anggota-nya kecanduan Narkoba (Narkotika dan Obat-obat terlarang). Kecanduan Narkoba atau dengan istilah lain NAZA (Narkotika, Alkohol dan ZatAdiktif lainnya), merupakan penyakit sosial yang akut yang sangat ditakuti oleh setiap keluarga, masyarakat 
maupun pemerintah. Hal ini sangat beralasan, karena Narkoba bukan saja membahayakan kesehatan jasmani, dan kesehatan rohani malah lebih parah lagi bisa menghancurkan kesehatan sosial.

Biarpun Narkoba itu, pertama kali dikonsumsi manusia sebagai obat, namun karena kesehatan dalam penggunaannya bisa menjadi penyakit menularyang sangat berbahaya, dan dapat menyebar cepat melalui pergaulan, terutama di kalangan usia muda (remaja). Penyakit ini dapat mematikan terutama kreatifitas kehidupan generasi muda, oleh karena itu semua negara di dunia memaklumkan perang terhadap penyalahgunaan Narkoba. Namun kenyataan menunjukkan bahwa baik secara kualitas maupun kuantitas Narkoba secara cepat tetap memangsai generasi muda. Dari latar belakang di atas, mengundang berbagai pertanyaan. Kenapa orang bisa kecanduan Narkoba? Mengapa pecandu Narkoba itu susah untuk di atasi, baik oleh keluarga, masyarakat maupun pemerintah ? Dan bagaimana solusi yang ditawarkan Psikologi Dakwah dalam mengatasi masalah tersebut?

Melalui penelaahan dari berbagai literatur akhirnya penulis mencoba menawarkan beberapa solusi dalam menangani kasus narkoba. Solusi yang dipaparkan di sini disesuaikan dengan prinsip-prinsip Psikologi Dakwah.

\section{Pengertian Narkoba}

Narkoba adalah singkatan dari "Narkotika dan Obat-obat terlarang", dengan demikian dapat dipisahkan antara narkotika dengan obat-obat terlarang. Narkotika diartikan bahan-bahan pembius atau obat-obat bius. ${ }^{1}$ Sedangkan obat-obat terlarang banyak jenisnya, antara satu dengan lainnya, punya pengaruh berbeda terhadap keadaan fisik maupun mental seseorang. Istilah lain yang tidak kalah terkenalnya "NAZA", yaitu singkatan dari Narkotika, Alkohol, dan Zat Adiktiv lainnya.

Jenis-jenis obat (drug atau farmakon) didefinisikan oleh WHO sebagai "Semua zat yang bila dimasukkan ke dalam tubuh suatu makhluk, akan mengubah atau mempengaruhi satu atau lebih fungsi faaliah makhluk tersebut". ${ }^{2}$ Dalam masalah ketergantungan obat, biasanya yang dimaksud

${ }^{1}$ Maramis, WF. 1988. Ilmu Kedokteran Jiwa. Surabaya : Air Langga University Press. hlm.34.

${ }^{2}$ Ibid. 
dengan obat ialah: Zat dengan efek yang besar terhadap susunan saraf pusat atau fungsi mental, seperti obat psikotropik, termasuk obat psikotomimetik (psikedelik) dan stimulansia, morfin dan derivatnya serta obat tidur. "Opioid" ialah semua zat, asli atau sintetik, yang mempunyai efek seperti morfin. Sedangkan Narkoba sebenarnya secara farmakologik berarti obat-obat yang menekan susunan saraf pusat, terutama opionid, tetapi sebagian ahli hendak memasukkan juga tranguilaizer, neroleptika, dan hipnotika ke dalam kelompok narkotika. Menurut peraturan kita di Indonesia, dalam narkotika termasuk juga kokain dan psikotomimetika (ganja). ${ }^{3}$

Opioid yang terkenal adalah opium, morfin, heroin, kodein dan petidin. Efek satu dosis tunggal morfin atau aploid yang lain ternyata tergantung pada pengalaman individu dengan obat tersebut sebelumnya, pada kepribadiannya, adanya atau tidak adanya rasa nyeri serta tergantung pula pada keadaan dan suasana pemakaian.

Semua jenis Narkoba (Naza) tersebut diproduk dalam dua bentuk kemasan; Pertama diproduk khusus untuk kepentingan "obat-obatan" dan bisa dipakai dengan resep dokter. Kedua dikemas khusus untuk kepentingan "bisnis", dalam bentuk kedua ini baik proses produksinya, proses pemasarannya, maupun yang mengkonsumsinya tetap sifatnya ilegal.

\section{Sebab-Sebab Kecanduan Narkoba}

Sebagaimana telah dijelaskan di atas, pada dasarnya Narkoba itu adalah obat yang sangat dibutuhkan oleh dunia kedokteran, tanpa adanya jenis-jenis obat tersebut, penyakit-penyakit tertentu ada yang tidak bisa ditolong, tetapi penyalahgunaan-nya itu yang menjadi masalah.

Sasaran utama Narkoba adalah remaja, hanya sebagian kecil yang bukan dari kelompok mereka. Menurut hasil dari suatu penelitian bahwa $64 \%$ pecandu Narkoba berasal dari mereka yang usia antara 16 - 18 tahun.

Mengapa usia remaja merupakan sasaran empuk dari pecandu Narkoba ? Ditinjau dari ilmu Psikologi, usia remaja mempunyai beberapa ciri khas tertentu, yaitu : 1). Masa remaja sebagai periode yang penting, 2). Masa remaja sebagai periode peralihan, 3). Masa remaja sebagai periode perubahan,

${ }^{3}$ Ibid, hlm. 35. 
4). Masa remaja sebagai usia bermasalah, 5). Masa remaja sebagai masa mencari identitas, 6). Masa remaja sebagai usia yang menakutkan, 7). Masa remaja sebagai masa yang tidak realistis, dan 8). Masa remaja sebagai ambang masa dewasa. ${ }^{4}$

Dari delapan ciri khas remaja sebagaimana disebutkan di atas, bila dihubungkan dengan pertanyaan, kenapa usia remaja menjadi sasaran Narkoba? Hal ini disebabkan karena :

a. Kepribadian

Masa remaja itu "seperti badai yang menggoncang-goncang', mereka belum mengetahui siapa dia yang sebenarnya, sehingga jiwanya mengembara mencari identitas dirinya. Masa anak-anak tersebut, dirasakan sebagai masa sulit dan penuh ketakutan dan kekosongan. Si remaja ingin mengidentifikasi dirinya dengan figur-figur kesukaannya. Dalam kekosongan identitas diri inilah sang remaja cenderung bertindak tidak realistis, ${ }^{5}$ dan sangat rawan terhadap pengaruh-pengaruh negatif, termasuk kesenangan sementara, seperti penggunaan Narkoba.

b. Keadaan Jiwa

Jiwa para remaja adalah sangat labil (tidak stabil), mereka sangat mudah terkena stres, depresi atau kecemasan. Hal ini disebabkan di usia tersebut perubahan bentuk tubuh sangat cepat, tidak diimbangi dengan perkembangan mentalnya. Para ahli berpendapat bahwa hakikat masa ini ialah kematangan kehidupan seksual. Sementara mereka belum punya pengetahuan mengenai hal itu. Dalam keadaan yang serba tidak siap inilah, secara psikologis mengundang perasaan tegang, stres, cemas dan gelisah. Kalau dalam keadaan seperti ini mereka tidak mendapatkan bimbingan dan pengarahan dari orang dewasa baik dari orang tua maupun guru, maka mereka akan terseret menuju penyelesaian semu, seperti mabukmabukan, mengisap ganja, minum XTC dan lain sebagainya.

c. Keluarga

Keluarga adalah wadah dimana anak dilahirkan dan dipersiapkan untuk menjadi orang dewasa yang mandiri. Keberhasilan anak sangat

${ }^{4}$ Hurlock, EB. 1997. Psikologi Perkembangan Suatu Pendekatan Sepanjang Rentang Kehidupan. Jakarta: Erlangga. hlm. 97.

${ }^{5} \mathrm{Ibid}, \mathrm{hlm} .98$ 
ditentukan oleh keberhasilan keluarga dalam mempersiapkan anak menuju masa dewasa.

Untuk menggapai keberhasilan ini, hubungan yang terbuka dan harmonis serta saling pengertian antara orang tua dengan si remaja, merupakan salah satu persyaratan yang sangat menentukan. Dengan komunikasi yang terbuka tersebut, memudahkan si remaja dalam mencari solusi menghadapi berbagai masalah hidup yang biasanya sangat kompleks pada masa-masa yang kritis ini, sehingga mereka tidak melarikan diri ke kelompok remaja yang rusak dan tidak bermoral.

Kegagalan pendidikan keluarga merupakan penyebab anak tidak dapat beradaptasi ataupun menyesuaikan diri dengan dirinya sendiri, dengan keluarganya maupun dengan lingkungan sosial yang lebih luas. Lebih jauh anak atau remaja akan terjerumus ke dunia primitif, kriminal dan patalogis, dan hal ini biasanya dimulai dengan mengkonsumsi Narkoba.

d. Tingkat Keimanan Keluarga

Keimanan merupakan polisi batin yang bertugas mengawasi perilaku lahiriah setiap manusia. Bila dalam belasan tahun anak-anak dipersiapkan imannya dengan baik, dia akan siap mengontrol dirinya ketika dia terlepas dari pengawasan orang tua. Pembinaan iman dan amal shalih secara dini, sangat membantu dia waktu memasuki usia remaja. "Sikap dan minat remaja terhadap masalah keagamaan boleh dikatakan sangat kecil dan hal ini tergantung dari kebiasaan masa kecil serta lingkungan agama yang mempengaruhi mereka". ${ }^{6}$ A.A. Brill, seorang psikoanalisa mengatakan "Individu yang benar-benar religius tidak akan pernah menderita sakit jiwa". ${ }^{7}$ Sebaliknya anak-anak yang memasuki usia remaja sementara mereka belum punya nilai-nilai spritual, kemungkinan lebih mudah terjerumus ke dalam perilaku menyimpang (gangguan jiwa).

e. Kelompok Sebaya

Ketika si remaja mengalami kegoncangan jiwa, lalu dia tidak men-dapatkan perhatian khusus dari orang tuanya, di saat itu anak mencari teman senasip sepenanggungan, yang mau memperhatikan berbagai keluhan

${ }^{6}$ Jalaluddin. 1997. Psikologi Agama. Jakarta; Raja Grafindo. hlm.74.

${ }^{7}$ M.Utsman Najati. 1997. Al-Qur'an dan Ilmu Jiwa. Bandung : Pustaka. hlm. 288. 
dan keresahan jiwanya. Mereka secara bersama-sama ingin mendapatkan berbagai kepuasan walaupun sifatnya hanya sementara, melaluipenggunaan Narkoba.

Su'dan mengemukakan beberapa sebab seseorang kecandungan Narkoba yaitu: "Sebagai manifestasi kelainan kepribadian dan kenakalan remaja. Mungkin pula sebagai akibat dari usaha pengobatan sendiri bagi si sakit. Ada pula yang beranggapan bahwa obat-obat itu mempunyai kekuatan istimewa. Juga dapat menguatkan sex, dan yang lain mengatakan untuk diterima dalam gengnya". ${ }^{8}$ Sedangkan Maramis menyimpulkan beberapa penyebab kecanduan Narkoba adalah "secara holistik dapat dicari dalam keperibadian, sosiol budaya dan badaniah, yang mengadakan intraksi yang kompleks sehingga menimbulkan gangguan itu". ${ }^{9}$

\section{Bahaya Narkoba}

Narkoba tidak lagi hanya merupakan musuh Islam, namun sudah diakui sebagai bahaya bagi setiap masyarakat dunia secara umum, karena melalui banyak penelitian menunjukkan bahwa, terdapat hubungan yang bermakna antara pecandu Narkoba dengan berbagai prilaku kriminal. Dalam hal ini Allah berfirman: "Mereka bertanya kepadamu tentang khamar dan judi, katakanlah! Pada keduanya itu terdapat dosa besar dan beberapa manfaat bagi manusia, tetapi dosa keduanya lebih besar dari manfaatnya". (QS. 2:219).

Narkoba merupakan penjabaran dari khamar, karena semua jenis tersebut mengudang banyak dosa. Dari Narkoba itu akan tumbuh dan bercabang perbuatan keji lainnya yang tidak kalah jelek akibatnya; seperti copet, curi, rampok, judi, zina dan lain sebagainya. Allah berfirman: "Sesungguhnya setan itu bermaksud hendak menimbulkan permusuhan dan kebencian di antara kamu lantaran (minuman) khamar dan berjudi itu, dan menghalangi kamu dari mengingat Allah dan salat; maka berhentilah kamu (dari mengerjakan pekerjaan itu). (QS. 5:9).

Pekerjaan dosa yang digambarkan dalam Islam itu, selalu berkono-

${ }^{8}$ Su'dan, MD. 1997. Al-Qur'an dan Panduan Kesehatan Masyaraka. Yogyakarta: Dana Bakti Prima Yasa. hlm.112.

${ }^{9}$ Maramis. Ilmu.... hlm.38 
tosi negatif, baik bagi si pelaku, keluarga maupun masyarakatnya. Dari hasil penelitian Hawari, membuktikan bahwa penyalahgunaan Narkoba menimbulkan dampak antara lain, "merusak hubungan kekeluargaan, menurunkan kemampuan belajar, ketidakmampuan untuk membedakan mana yang baik dan buruk, perubahan prilaku menjadi anti sosial, kekerasan lainnya baik kuantitatif maupun kualitatif". ${ }^{10}$.

Permasalahan penyalahgunaan Naza (Narkoba) mempunyai dimensi yang luas dan komplek; baik dari sudut medik, psikiatrik, kesehatan jiwa, maupun psikososial (ekonomi, politik, sosial budaya, kriminalitias dan lain sebagainya). ${ }^{11}$

Sedangkan Su'dan mengatakan bahwa 'Narkoba itu sangat membahayakan baik bagi kesehatan jasmani, kesehatan rohani maupun terhadap kesehatan sosial". ${ }^{12}$

Dengan demikian bahaya Narkoba itu sifatnya holistik (menyeluruh) tidak hanya mengganggu kesehatan jasmani bagi si pelaku, kesehatan rohaninya malah bisa merusak kesehatan sosial kemasyarakatan.

\section{Pendekatan Psikologi Dakwah}

Pendekatan Psikologi Dakwah yang dimaksudkan adalah cara-cara yang ditempuh dalam mengubah sikap dan perilaku mad'u, melalui akal sehat, diterima secara suka rela dan senang hati, sesuai dengan ciri khas kejiwaan yang Islami, tidak dipaksakan. Cara-cara tersebutselalu disesuaikan dengan princip-prinsip persuasif, motivatif, konsultatif dan edukatif.

Secara umum, dalam dunia kedokteran dikenal tiga tingkatan dalam memberikan bantuan terhadap pasiennya, yaitu preventif, kuratif dan rehabilitasi. Bantuan semacam ini cocok untuk mereka yang kecanduan Narkoba.

\section{Preventif/Promosi Kesehatan}

Mencegah dari suatu penyakit jauh lebih bijaksana dibandingkan

${ }^{10}$ Dadang Hawari. 1997. Ilmu Kedokteran Jiwa Dan Kesehatan Jiwa. Yogyakarta: Dana Bhakti Prima Jaya. hlm.74.

${ }^{11} \mathrm{Ibid}$, hlm.70.

${ }^{12}$ Su'dan. Al-Qur'an..... hlm.115. 
mengobati setelah sakit. Dengan cara seperti ini dapat mengurangi modal dan resiko. Rasulullah bersabda: Artinya: "Pencegahan pangkal dari segala pengobatan". (Hadits). "Prevention is better than cure", petuah ini sudah sangat dikenal oleh ilmu kesehatan masyarakat, dan ilmu kedokteran. Cara semacam ini sangat mudah karena tidak punya efek samping, baik secara pisik maupun secara psikologis. Padahal Islam sangat menganjurkan umatnya untuk mencari jalan termudah dalam menyelesaikan berbagai permasalahan. Sebagaimana nasehat Rasulullah kepada Ali bin Abi Thalib dan Mu'az bin Jabal ketika berangkat ke negeri Yaman, "Permudahlah dan jangan mempersulit, gembirakanlah dan jangan berbuat sesuatu yang menyebabkan mereka lari dari padamu". ${ }^{13}$

Hadits di atas mengingatkan agar memilih cara yang paling mudah dalam menyelesaikan suatu masalah. Demikian halnya masalah Narkoba, beri pendidikan kepada remaja, bagaimana akibat kerusakan baik fisik maupun mental mereka yang kecanduan Narkoba tersebut, baik bagi dirinya, keluarganya maupun sosial kemasyarakatan-nya.

Preventif atau mencegah Narkoba ini, tidak hanya dengan pendidikan kesehatan, dengan berbagai bentuk promosi, tapi juga bisa dalam bentuk ancaman hukuman berat bagi si pelaku. Sebenarnya bukan hukuman berat ini yang ditonjolkan tetapi bagaimana cara, agar orang takut dan tidak mau memulai perbuatan tersebut.

\section{Kuratif/Pengobatan}

Bila suatu penyakit dalam bentuk fisik/biologis, tentu saja pengobatannya melalui berbagai macam cara baik dalam bentuk obat, maupun operasi atau kalau perlu diamputasi. Lain halnya dengan kecanduan Narkoba, kepada mereka diberikan obat dilanjutkan dengan terapi medik, dan tidak jarang si penderita baru sembuh setelah diterapi dengan terapi spritual. Artinya, usahakan agar mereka kembali ke jalan yang benar, dengan berbagai macam cara persuasif, dan bijaksana sehingga mereka secara suka rela bersedia meninggalkan perbuatan keji tersebut. Cara ini terangkum dalam Al-Qur'an

${ }^{13}$ Hamka. 1084. Prinsip dan Kebijaksanaan Da'wah Islam. Jakarta: Pustaka Panjimas. hlm. 87. 
surat An-Nahl: 125. Artinya : "Serulah (mereka) ke jalan Tuhanmu dengan hikmah, pendidikan yang baik dan berdiskusilah dengan mereka secara baik ...". (QS. 16: 125). Dalam Al-Qur'an Surat Ali Imran 159 Artinya: "Maka karena rahmat Allah, engkau (Muhammad) dapat bertindak lemah lembut kepada mereka, dan jika engkau berlaku kasar dan keras hati maka mereka akan melarikan diri kepadamu. Maka maafkanlah mereka, dan mintalah ampun atas dosa mereka...." (QS. 3:159).

Metode pendekatan yang ditonjolkan dalam dua ayat di atas, cara yang mengandung kelembutan dan kesejukan sehingga diharapkan mereka yang sudah terlanjur tergugah hatinya, secara sukarela kembali ke jalan yang benar.

\section{Rehabilitasi}

Bagi orang yang sudah sembuh dari penyakit, diusahakan agar bertambah sehat; kepada mereka diberikan berbagai latihan, yang sifatnya mengarah kepada pencegahan supaya tidak terulang kembali. Demikian halnya bagi mereka yang terlibat Narkoba, tetapi telah bertobat, diusahakan agar keluarga dan masyarakat menerimanya dan melibatkan mereka dalam berbagai aktivitas sosial, tanpa mengungkitkan masa lalunya yang penuh dengan kemesuman. Dengan cara tersebut mereka tidak merasa terasing dan bisa hidup secara wajar dan normal di dalam masyarakatnya.

Dalam merealisasikan tiga prinsip pokok pendekatan Psikologi Dakwah dalam menanggulangi, mengobati dan merehabilitasi pecandu Narkoba, perlu adanya kerjasama dari berbagai pihak.

\section{a. Keluarga}

Keluarga sebagai pendidik utama dan pertama yang diterima anak dengan segala daya upaya mereka mempersiapkan anaknya agar berhasil melewati masa remaja yang penuh dengan berbagai cobaan. Ada beberapa persyaratan untuk mewujudkan cita-cita tersebut, yaitu :

1. Mengisi batin anak-anaknya dengan iman, amal dan akhlakul karimah.

2. Menjaga keserasian hubungan antara suami isteri, sehingga tidak terjadi pertengkaran di depan anak-anak, hal ini dapat menyebabkan anak stres, cemas, kacau dan gelisah. Pada akhirnya kepribadian anak terganggu. 
3. Komunikasi; timbal balik antara anak, orang tua dan anggota keluarga secara terbuka, sopan dan harmonis. Si anak tidak segan-segan membicarakan permasalahannya kepada orang tua, sehingga mereka betah di rumah dan tidak lari mencari teman yang mau mendengar berbagai keluhan mereka.

b. Sekolah

Fungsi sekolah bukan hanya mengisi koqnisi aak-anak dengan berbagai macam ilmu pengetahuan, malah peran iman, sangat menonjol dalam mempersiapkan generasi muda. Sebaiknya semua guru bisa meng-hubungkan setiap keterangan dari bidang studi yang diajarkan dengan iman dan amal shalih, agar semua ilmu pengetahuan yang diperoleh anak tidak kalah pentingnya untuk mendapatkan perhatian, dan pembinaan dari guru, sehingga mereka tidak mudah terjerumus ke dunia fantasi lewat kebahagiaan semu, termasuk Narkoba.

\section{c. Masyarakat}

Masyarakat adalah lingkungan dimana anak-anak hidup dan mengembangkan koqnisi, afeksi, konasi dan psichomotornya. Bilamana lingkungan sosial anak rusak, secara tidak langsung masyarakat tersebut sedang mengorbitkan generasi muda yang rusak serta tidak bermoral.

Masyarakat ikut bertanggung jawab dalam membina putra-putrinya, secara bersama melaksanakan pembinaan dan pengontrolan terhadap generasi mudanya. Mereka ikut memikirkan kegiatan apa saja yang bisa dipercayai kepada generasi muda. Masyarakat juga perlu mengarahkan para muda-mudi mereka dalam berbagai bentuk organisasi yang sesuai dengan umur dan kemampuan mereka, seperti; Remaja Mesjid, Olah raga, Kepramukaan Karang Taruna dan lain sebagainya.

Kesibukan tersebut akan mengisi waktu luang mereka, sehingga tidak sempat menghabiskan waktu dengan hal yang tidak bermanfaat, yang pada akhirnya menggiring mereka kepada keonaran, Narkoba, pergaulan bebas, perjudian, perampokan dan tindak kriminal lainnya. 
d. Pemerintah

Pada dasarnya Pemerintah dimanapun tidak menginginkan generasi mudanya rusak dan hancur karena Narkoba. Tetapi kesalahan menetapkan kebijaksanaan yang membuat mereka kecolongan, dalam pembinaan generasi mudanya, sehingga tidak sedikit para remaja terlibat Narkoba.

Undang-undang yang berat saja tidak cukup terhadap mereka yang terlibat Narkoba, kalau tidak didukung dengan proses pelaksanaan pengadilan yang betul-betul serius, tidak pilih kasih serta tidak ada unsur KKN.

\section{e. Kepolisian}

Siapapun mengetahui bahwa polisi bertugas menegakkan hukum; artinya, melindungi setiap orang teraniaya dan menindak keras orang yang melanggar hukum, seperti penganiayaan, pemerkosaan, pencurian, penipuan, pembunuhan, perjudian dan semua tindakan itu banyak yang berasal dari pecandu Narkoba.

Bila polisi konsekwen melaksanakan tugasnya dalam memberantas berbagai macam penyakit sosial, sehingga tidak ada istilah kebal hukum, mudah-mudahan Narkoba dan sejenisnya berangsur-angsur akan sirna.

\section{f. Ulama}

Ulama adalah orang berilmu, dalam arti mengerti minimal ilmu pengetahuan agama, jauh lebih baik lagi menguasai ilmu secara luas dan umum. Mereka tidak hanya ahli ilmu tetapi juga ahli dalam penerapannya. Hal ini sangat berpengaruh kepada kehidupan mental-rohaniah para pengikutnya, sehingga ucapan-ucapan yang keluar dari mulut ulama, akan menjadi obat penyembuh terhadap berbagai penyakit mental, bahkan dijadikan pegangan hidup bagi mereka. ${ }^{14}$

Ulama tidak hanya memfokuskan diri terhadap orang-orang yang berkumpul di mesjid, surau atau meunasah, tetapi di pundak mereka juga terletak tanggung jawab pembinaan generasi muda, yang tidak mengenal tempat-tempat suci tersebut. Dalam menyelamatkan generasi muda, ulama

${ }^{14}$ Arifin. 1994. Teori-teori Counseling. Jakarta: Golden Terayon Press. hlm. 54. 
punya peran tersendiri, baik dalam usaha preventif, kuratif maupun rehabilitasi, baik bagi mereka yang sudah terjerumus ke dunia Narkoba maupun yang belum. ${ }^{15}$

Penggunaan media komunikasi modern tidak dapat dihindari, karena hanya melalui media inilah semua mad'u dapat terjaring, tidak terkecuali mereka yang kecanduan Narkoba. Media elektronik seperti radio, tape recorder, VCD dan CD Room, serta internet tidak lagi dianggap tabu, malah suatu keharusan, kalau para ulama tersebut tidak mau menemui kegagalan dalam membina generasi.

\section{Penutup}

Penyalahgunaan Narkoba adalah suatu kejahatan dan akan membawa dampak buruk, terutama kepada si pelakunya. Akibat ini bukan saja memburuknya kesehatan fisik dan mental, malah lebih jauh dari itu akan menghancurkan masa depannya. Sedangkan akibatnya bagi keluarga adalah dengan mengkonsumsi Narkoba, si remaja susah diatur, tidak disiplin, suka membantah orang tua, suka bertengkar dengan saudara-saudaranya dan pada akhirnya dia merasa dimusuhi di dalam keluarganya sendiri. Di samping itu nama baik suatu keluarga akan rusak bila ada salah seorang di antara anggota keluarganya kecanduan Narkoba.

Penyalahgunaan Narkoba merupakan suatu benih kejahatan, jika benih ini dibiarkan tumbuh dalam suatu masyarakat, cepat atau lambat akan tumbuhlah cabang-cabangnya yang lain dalam berbagai bentuk kriminal, seperti copet, pencurian, perjudian, pergaulan bebas, perkelahian dan lain sebagainya. Dengan demikian ketenangan dan ketentraman masyarakat pasti akan terganggu.

Karena akibat dari penyalahgunaan Narkoba itu demikian kompleks, seyogyanyalah semua pihak bertanggung jawab, kerjasama dan bahu membahu dalam menanggulanginya, baik dalam bentuk preventif, kuratif, maupun rehabilitatif. Dalam mengatasi problema Narkoba tersebut sebaiknya semua pihak memperhatikan metode Psikologi Dakwah yaitu dengan cara merobah sikap dan prilaku mad'u, melalui akal sehat, diterima secara suka rela dan

${ }^{15}$ Su'dan. Al-Qur'an.... hlm.123. 
senang hati, sesuai dengan ciri khas kejiwaan yang Islami, tidak dipaksakan. Cara-cara tersebut selalu disesuaikan dengan prinsip-prinsip persuasif, motivatif, konsultatif dan edukatif. 


\section{DAFTAR PUSTAKA}

Achmad Mubarok. 1999. Psikologi Dakwah, Jakarta : Pustaka Firdaus Akhlaq, Husain, 2000, Menjadi Orang Tua Muslim Terhormat, Surabaya: Risalah Gusti

Arifin, M, 1994, Psikologi Dakwah Suatu Pengantar, Jakarta: Bumi Aksara Press 1994, Teori-teori Counseling, Jakarta: Golden Terayon

Dagur, SM, 1990, Psikologi Keluarga, Jakarta: Rineka Cipta

Departemen Agama RI, 1989, Al-Qur'an dan Terjemahnya, Semarang: Toha Putra

Fadhlullah, M.H, 1997, Metodologi Dakwah Dalam Al-Qur'an, Jakarta: Lentera

Faizah dan Lalu Muchsin Effendi. 2006. Psikologi Dakwah, Jakarta: Kencana Hamka, 1984, Prinsip dan Kebijaksanaan Da'wah Islam, Jakarta: Pustaka Panjimas

Hawari, Dadang, 1997, Ilmu Kedokteran Jiwa Dan Kesehatan Jiwa, Yogyakarta:

Dana Bhakti Prima Jaya

Hurlock, EB, 1997, Psikologi Perkembangan Suatu Pendekatan Sepanjang Rentang Kehidupan, Jakarta: Erlangga

Jalaluddin, 1997, Psikologi Agama, Jakarta; Raja Grafindo

Maramis, WF, 1988, Ilmu Kedokteran Jiwa, Surabaya : Air Langga University Press

Najati, Utsman, M, 1997, Al-Qur'an dan Ilmu Jiwa, Bandung : Pustaka Su'dan, MD, 1997, Al-Qur'an dan Panduan Kesehatan Masyarakat, Yogyakarta: Dana Bakti Prima Yasa 